\title{
Effects of rock fragments on physical degradation of cultivated soils by rainfall
}

\author{
Bas van Wesemael ${ }^{\mathrm{a}, *}$, Jean Poesen ${ }^{\mathrm{a}, \mathrm{b}}$, Tomás de Figueiredo ${ }^{\mathrm{c}}$ \\ ${ }^{a}$ Laboratory for Experimental Geomorphology, K.U. Leuven, Redingenstraat 16 bis, 3000 Leuven, \\ Belgium \\ ${ }^{b}$ National Fund for Scientific Research, Redingenstraat 16 bis, 3000 Leuven, Belgium \\ 'Escola Superior Agrária de Bragança, Apartado 172, 5300 Bragança, Portugal
}

Accepted 20 October 1994

\begin{abstract}
To understand better the role of rock fragments in soil and water conservation processes, the effects of rock fragments in maintaining a favourable soil structure and thus also in preventing physical degradation of tilled soils was studied. Laboratory experiments were conducted to investigate the effects of rock fragment content, rock fragment size, initial soil moisture content of the fine earth and surface rock fragment cover on soil subsidence by rainfall (i.e. change in bulk density by onc or morc cycles of wetting and drying). A total of 15 rainfall simulations (cumulative rainfall, $192.5 \mathrm{~mm}$; mean intensity, $70 \mathrm{~mm}$ $\mathrm{h}^{-1}$ ) were carried out. Before and after each rainfall application the surface elevation of a 19-cm thick plough layer was measured with a laser microrelief meter. In all experiments, the bulk density of the fine earth increased with applied rainfall volume to reach a maximum value at about $200 \mathrm{~mm}$ of cumulative rainfall. From the experimental results it was concluded that the subsidence rate decreased sharply for soils containing more than 0.50 $\mathrm{kg} \mathrm{kg}^{-1}$ rock fragments, irrespective of rock fragment size. Fine earth bulk densities were negatively related to rock fragment content beyond a threshold value of $0.30 \mathrm{~kg} \mathrm{~kg}^{-1}$ for small rock fragments $(1.7-2.7 \mathrm{~cm})$ and $0.50 \mathrm{~kg} \mathrm{~kg}^{-1}$ for large rock fragments $(7.7 \mathrm{~cm})$. Initial soil moisture content influenced subsidence only in the initial stage of the experiments, when some swelling occurred in the dry soils. Surface rock fragment cover had no significant effect on subsidence of the plough layer. Therefore, subsidence of the plough layer in these experiments appears to be mainly due to changing soil strength upon drainage rather than the result of direct transfer of kinetic energy from falling drops. The relative increase in porosity of the fine earth as well as the absolute increase in macroporosity with rock fragment content will cause deeper penetration of rainfall into the soil, resulting in water conservation. Therefore, crushing of large rock fragments into smaller ones is to be preferred over removal of rock fragments from the plough layer.
\end{abstract}

\footnotetext{
${ }^{*}$ Corresponding author.
} 
Keywords: Rock fragments; Physical soil degradation; Bulk density; Subsidence; Tillage; Water conservation

\section{Introduction}

In many countries of the Mediterranean basin and elsewhere, where degradation of the natural environment constitutes a serious problem leading to desertification, a large proportion of the soils contain rock fragments both at the soil surface and in the soil profile (Poesen and Lavee, 1994). Recent research in Greece has shown that soils derived from sandstones and conglomerates containing rock fragments are, despite their low fertility, less affected by dry periods than soils on marls without rock fragments, resulting in higher wheat biomass production for the first soil types (Kosmas et al., 1993). Kosmas et al. (1993) mention the higher bulk density of the fine earth in the marls and their higher water storage capacity as factors which cause penetration of rainfall into the soil to be less deep and subsequent evaporation from the soil surface to be more rapid as compared with soils containing rock fragments. These results suggest that apart from the protective role of rock fragments at the soil surface (see literature review by Poesen and Bunte, 1995), rock fragments in the soil profile play an important role in conserving soil moisture during the growing period.

In agricultural soils, which are disturbed every year by ploughing, rock fragments form a skeleton in the soil profile which protects soil structure leading to a higher macroporosity and saturated hydraulic conductivity (Saini and Grant, 1980; Magier and Ravina, 1984: Ravina and Magier, 1984; Childs and Flint, 1990: Chow et al., 1992). This is in contrast with the results of Mehuys et al. (1975), who found that in non-structured desert soils saturated hydraulic conductivity decreased with increasing rock fragment content. In addition, some authors (Childs and Flint, 1990; Poesen and Lavee, 1994) stated that in soils containing rock fragments concentration of organic matter in the fine earth fraction occurs, leading to low fine earth bulk densities at high rock fragment contents.

Freshly tilled soils are prone to physical degradation of the plough layer as a result of drop impact and percolation of water during heavy rainstorms (Onstad et al., 1984). Physical degradation refers to adverse changes in soil physical properties including porosity, permeability, bulk density and structural stability (FAO, 1979). Physical degradation results in an increase of soil bulk density (subsidence). According to Onstad et al. (1984) the most important factors responsible for subsidence of freshly tilled soils are the kinetic energy transferred to the soil surface by rainfall and changing soil strength with water content as soil water moves through the tilled layer. Soil subsidence reduces the proportion of structural pores which has a negative effect on the saturated hydraulic conductivity and on the development of the root system and a positive effect on capillary rise and evaporation of moisture from the topsoil (Ravina and Magier, 1984). Since these parameters play a crucial role in the availability of water for the vegetation 
and the control of soil erosion, they become more important in ecosystems with desertification hazards.

The experiments described in this paper were designed to study the influence of the content, size and surface cover of rock fragments and the initial moisture content of the fine earth, on the physical degradation of tilled soils during intense rainfall.

\section{Materials and methods}

\subsection{Rainfall}

Rainfall was simulated by a downward-oriented, single-nozzle, continuous-spray system described in detail by Poesen et al. (1990). These authors showed that at an average intensity of $71.1 \mathrm{~mm} \mathrm{~h}^{-1}$ (standard deviation: 3.96 ) and a spatial uniformity coefficient of $94 \%$, the median raindrop diameter equals $2.2 \mathrm{~mm}$. The kinetic energy of the simulated rain (fall height, $3.25 \mathrm{~m}$ ) at the soil surface then reaches $15.8 \mathrm{~J} \mathrm{~m}^{-2} \mathrm{~mm}^{-1}$ of rain.

Rainfall intensity was sampled before and after each experiment. Total rainfall volume $(192.5 \mathrm{~mm})$ for each experiment consisted of four rainfall events lasting $15,30,60$ and 60 min respectively. These events were separated by no-rain periods of 2,24 and $2 \mathrm{~h}$ respectively. Mean intensities were $70 \mathrm{~mm} \mathrm{~h}^{-1}$.

\subsection{Experimental set up}

The plot box used in these experiments has been described in more detail by Poesen et al. (1990). The test area of the plot box is $0.94 \mathrm{~m}$ long and $0.60 \mathrm{~m}$ wide, surrounded by a buffer area 0.33 to $0.42 \mathrm{~m}$ wide. The latter was treated identically to compensate for splash losses. Drainage through the 0.19 -m thick layer of soil was ensured by installing at the bottom of the plot box a hollow, 1$\mathrm{cm}$ thick, perforated plate covered by a wet geo-textile. The volume of the box was $0.105 \mathrm{~m}^{3}$ (Fig. 1). The slope of the soil surface in the box equalled $15 \%$ in order to minimise the area where ponding occurs. For each experiment, the plot box was filled with a homogeneous mixture of fine earth and rock fragments simulating a freshly tilled soil (Table 1). The fine earth consisted of well-structured, homogeneous silt loam sampled in Neerijse (Belgium) at a depth of 30-60 cm. Subsoil was deliberately chosen to provide a material with a smaller structural stability than the local topsoil, since we expected the subsoil to have physical properties that were more similar to Mediterranean topsoils. A description of some soil properties (texture, bulk density, organic matter content and dry aggregate size distribution) is given in Table 2.

The small rock fragments used in these experiments are well-rounded river gravels from a quarry in Pleistocene river deposits of the Meuse. The gravels were sieved and only the fraction between 1.7 and $2.7 \mathrm{~cm}$ (round holes) was used. The large rock fragments $(d 2=7.7 \mathrm{~cm})$ were sampled in the channel of the Durance 


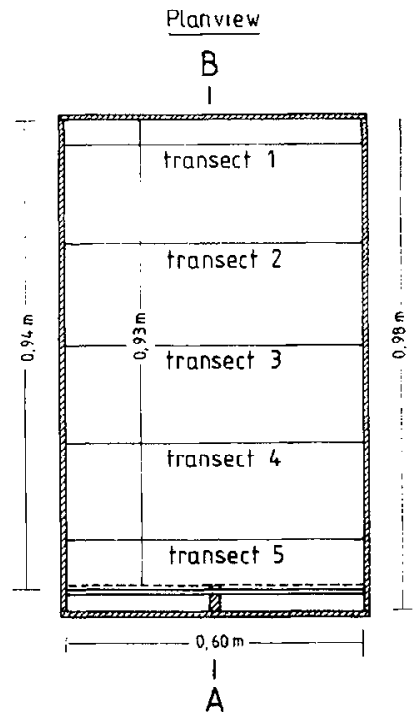

Cross section

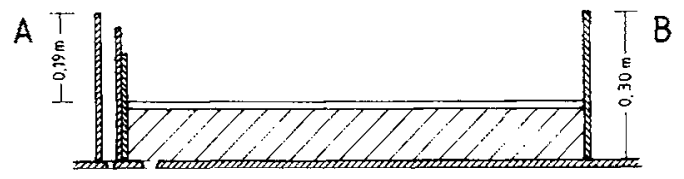

Fig. 1. Schematic view of the central test area.

river in southern France (Table 2). The small rock fragments fall in the medium to coarse gravel size class $(0.5-7.6 \mathrm{~cm})$, whereas the large ones are cobbles $(7.6-$ $25 \mathrm{~cm}$; Miller and Guthrie, 1984). The density of the rock fragments $\left(\rho_{\mathrm{r}}\right.$ in $\mathrm{kg}$ $\mathrm{m}^{-3}$ ) was calculated from the increase in volume after immersion of pre-weighed amounts of rock fragments in water (Table 2).

Percolation and runoff rates were determined at regular intervals during the simulation runs. The sediment concentration was determined by evaporation of the samples. Soil moisture content was determined gravimetrically before and after the experiments. During the intervals between the showers, the soil was left to drain. A plastic sheet prevented drying out of the soil by evaporation.

\subsection{Microrelief meter}

Five fixed transects were selected at 20-cm intervals (see Fig. 1) along which the soil surface elevations were determined at 2-mm intervals using a Selcom laser microrelief meter (Optacor 2008, Selcom A.G., Sweden) driven by a computer-controlled motor (Römkens et al., 1988). Scans were made before the experiment and after each rainstorm (Figs. 1 and 2 ). 
Table 1

Set-up of the experiments and volume of sediment trapped by the plot box rim

\begin{tabular}{|c|c|c|c|c|}
\hline \multirow{2}{*}{$\begin{array}{l}\text { Rock fragment size } \\
(\mathrm{cm})\end{array}$} & \multicolumn{2}{|c|}{ Rock fragment content } & \multirow{2}{*}{$\begin{array}{l}\text { Initial moisture } \\
\text { (g per } 100 \mathrm{~g} \text { ) }\end{array}$} & \multirow{2}{*}{$\begin{array}{l}\text { Volume of } \\
\text { sediment } \\
\left(\mathrm{dm}^{3}\right)\end{array}$} \\
\hline & $\begin{array}{l}R_{\mathrm{m}}^{\mathrm{a}} \\
\left(\mathrm{kg} \mathrm{kg}^{-1}\right)\end{array}$ & $\begin{array}{l}R_{\mathrm{v}}^{\mathrm{b}} \\
\left(\mathrm{m}^{3} \mathrm{~m}^{-3}\right)\end{array}$ & & \\
\hline Control & 0 & 0 & 20.0 & 1.38 \\
\hline Control & 0 & 0 & 19.4 & 1.27 \\
\hline Control & 0 & 0 & 18.7 & 1.23 \\
\hline $1.7-2.7$ & 0.31 & 0.16 & 20.4 & 0.46 \\
\hline $1.7-2.7$ & 0.52 & 0.29 & 19.6 & 0 \\
\hline $1.7-2.7$ & 0.52 & 0.28 & 19.1 & 0 \\
\hline $1.7-2.7$ & 0.77 & 0.46 & 21.1 & 0 \\
\hline 7.7 & 0.23 & 0.11 & 19.7 & 1.51 \\
\hline 7.7 & 0.52 & 0.30 & 19.7 & 0.64 \\
\hline 7.7 & 0.74 & 0.47 & 19.2 & 0 \\
\hline Control & 0 & 0 & 3.4 & 0 \\
\hline $1.7-2.7$ & 0.52 & 0.29 & 2.6 & 0 \\
\hline \multirow[t]{2}{*}{$1.7-2.7$} & 0.77 & 0.48 & 2.6 & 0.6 \\
\hline & \multicolumn{4}{|c|}{ Surface cover $(\%)$} \\
\hline $1.7-2.7$ & 30 & & 20.6 & 1.05 \\
\hline $1.7-2.7$ & 50 & & 19.0 & 0 \\
\hline
\end{tabular}

${ }^{\mathrm{a}} R_{\mathrm{m}}$ : rock fragment content by mass.

${ }^{\mathrm{b}} R_{\mathrm{v}}$ rock fragment content by volume at the beginning of the experiment.

${ }^{c}$ Volume calculated based on the difference between the mean height of the first four transects and the fifth one.

\subsection{Calculations}

In order to obtain a range of rock fragment contents by volume $\left(R_{\mathrm{v}}: 0-0.15-\right.$ $0.30-0.50 \mathrm{~m}^{3} \mathrm{~m}^{-3}$ ), the masses of fine earth and rock fragments of the simulated soil were calculated by means of Eqs. (1-5), using pre-estimated fine earth bulk densities:

$$
\begin{aligned}
& \gamma_{\mathrm{t}}=R_{\mathrm{v}} \rho_{\mathrm{r}}+\left(1-R_{\mathrm{v}}\right) \gamma_{\mathrm{fe}} \\
& R_{\mathrm{m}}=\frac{R_{\mathrm{v}} \rho_{\mathrm{r}}}{\gamma_{\mathrm{t}}} \\
& m_{\mathrm{r}}=R_{\mathrm{v}} \rho_{\mathrm{r}} V_{\mathrm{t}} \\
& R_{\mathrm{m}}=\frac{m_{\mathrm{r}}}{m_{\mathrm{t}}} \\
& m_{\mathrm{t}}=m_{\mathrm{f}}+m_{\mathrm{r}}
\end{aligned}
$$

where $\gamma_{\mathrm{t}}$ and $\gamma_{\mathrm{fe}}$ are the total and fine earth bulk density respectively $\left(\mathrm{kg} \mathrm{m}^{-3}\right)$, $R_{\mathrm{v}}$ is rock fragment content by volume $\left(\mathrm{m}^{3} \mathrm{~m}^{-3}\right), R_{\mathrm{m}}$ is rock fragment content 
Table 2

Characteristics of the fine earth and the rock fragments

a. Fine earth

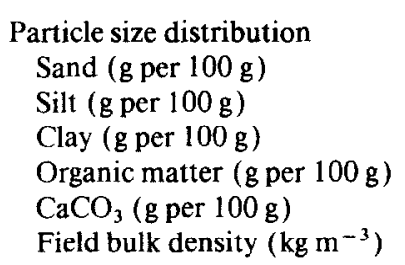

2

Dry aggregate size distribution ( $\mathrm{g}$ per $100 \mathrm{~g}$ )

\begin{tabular}{lcccccc}
\hline & $>31.5$ & $31.5-22.3$ & $22.3-11.2$ & $11.2-5.6$ & $5.6-2$ & $<2 \mathrm{~mm}$ \\
\hline Mean & 10 & 10 & 20 & 21 & 23 & 14 \\
Std $(n=32)$ & 2 & 3 & 3 & 2 & 3 & 3 \\
\hline
\end{tabular}

b. Rock fragments

$1.7-2.7 \mathrm{~cm}$ (medium to coarse gravels)

Size $(\mathrm{cm})$

Density $\left(\mathrm{kg} \mathrm{m}^{-3}\right)$

Length of the axes $(\mathrm{cm})$

\begin{tabular}{ccl}
\hline$d 1$ & $d 2$ & $d 3$ \\
\hline & & \\
10.8 & 7.7 & 4.4 \\
1.2 & 1.3 & 1.0 \\
2700 & & std: 88 \\
& & $(n=5)$
\end{tabular}

std, standard deviation.

by mass $\left(\mathrm{kg} \mathrm{kg}^{-1}\right), \rho_{\mathrm{r}}$ is rock fragment density $\left(\mathrm{kg} \mathrm{m}^{-3}\right), V_{\mathrm{t}}$ is total sample volume $\left(\mathrm{m}^{3}\right) m_{\mathrm{t}}, m_{\mathrm{r}}$ and $m_{\mathrm{f}}$ are total mass, mass of rock fragments and mass of fine earth, respectively $(\mathrm{kg})$.

According to Allmaras et al. (1967), the mean of the measured surface elevations can be used to calculate the volume of the sample before the experiment and after each shower $\left(V_{1}\right)$. The bulk density of the fine earth fraction $\left(\gamma_{\mathrm{fe}}\right)$ can then be calculated rearranging Eq. (1) as follows:

$$
\gamma_{\mathrm{fe}}=\frac{m_{\mathrm{f}}}{V_{\mathrm{t}}-\left(\frac{m_{\mathrm{r}}}{\rho_{\mathrm{r}}}\right)}
$$




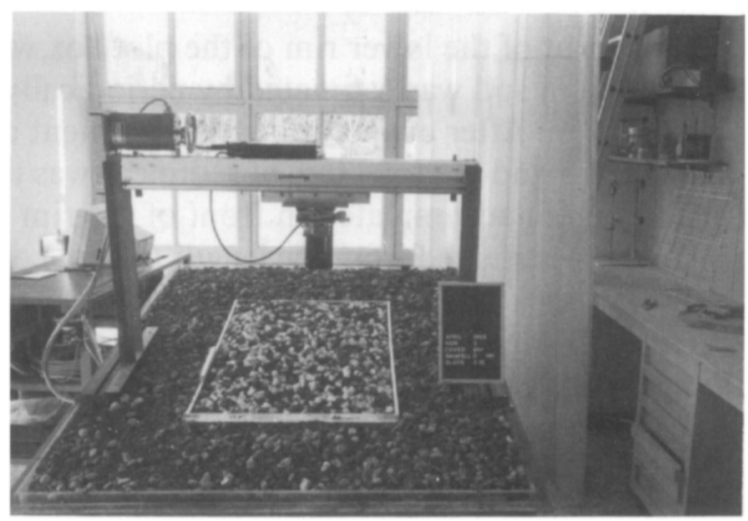

Fig. 2. Experimental set-up showing the laser microrelief meter and the plot box. Width of the central test area equals $60 \mathrm{~cm}$.

The rock fragment content by volume $\left(R_{\mathrm{v}}\right)$ also changes during the experiments and can be calculated with Eq. (3).

The porosity $\left(P: \mathrm{m}^{3} \mathrm{~m}^{-3}\right)$ of soils containing rock fragments was calculated from the density of the solid phase $\left(d_{s} ; \mathrm{kg} \mathrm{m}^{-3}\right)$ with the fine earth content by mass $\left(F_{\mathrm{m}} ; \mathrm{kg} \mathrm{kg}^{-1}\right)$, organic matter content by mass $\left(O_{\mathrm{m}} ; \mathrm{kg} \mathrm{kg}^{-1}\right)$ and rock fragment content by mass $\left(R_{\mathrm{m}} ; \mathrm{kg} \mathrm{kg}^{-1}\right)$ as well as their respective densities, $\rho_{\mathrm{f}}$ : $2650 \mathrm{~kg} \mathrm{~m}^{-3}, \rho_{\mathrm{o}}: 1470 \mathrm{~kg} \mathrm{~m}^{-3}$, and $\rho_{\mathrm{r}}$ (see Table 2) using Eqs. (7-8):

$$
\begin{aligned}
& d_{\mathrm{s}}=\frac{1}{\frac{F_{\mathrm{m}}}{\rho_{\mathrm{f}}}+\frac{O_{\mathrm{m}}}{\rho_{\mathrm{o}}}+\frac{R_{\mathrm{m}}}{\rho_{\mathrm{r}}}} \\
& P=\left(1-\frac{\gamma_{\mathrm{t}}}{d_{\mathrm{s}}}\right)
\end{aligned}
$$

The macroporosity at the end of the experiments ( $192.5 \mathrm{~mm}$ cumulative rainfall) was estimated from the difference between the total porosity and the volumetric water content of the fine earth $\left(\theta ; \mathrm{m}^{3} \mathrm{~m}^{-3}\right)$ after the plot box was allowed to drain for $1 \mathrm{~h}$. This parameter was calculated from the gravimetric moisture content $\left(w ; \mathrm{kg} \mathrm{kg}^{-1}\right)$ of the fine earth and the density of water $\left(\rho_{\mathrm{w}} ; 1000 \mathrm{~kg} \mathrm{~m}^{-3}\right)$ using Eq. (9).

$$
\theta=\frac{w \times \gamma_{\mathrm{fe}} \times\left(1-R_{\mathrm{v}}\right)}{\rho_{\mathrm{w}}}
$$

\subsection{Sources of error}

There are two sources of error associated with the experimental set-up. The first is caused by loss of soil material by runoff or percolation, and the second is 
due to sedimentation in front of the lower rim of the plot box when the soil surface has subsided. The loss of soil was estimated by periodically taking samples of the runoff and percolation. After evaporation, the sediment concentration in these samples was calculated and the total loss of sediment was thus estimated.

The volume of the sediment accumulated in front of the rim $\left(V ; \mathrm{dm}^{3}\right)$ at the end of each experiment was estimated from the length $\left(l_{\mathrm{d}} ; \mathrm{cm}\right)$ of the zone where deposition occurs and its thickness $\left(=0.15 \times l_{\mathrm{d}}\right.$ at a slope angle of $\left.15 \%\right)$. The length and the volume of the deposition zone were calculated from mean height of the first four transects $\left(h_{\mathrm{m}} ; \mathrm{cm}\right)$ and the fifth transect $\left(h_{5} ; \mathrm{cm}\right)$ at a distance of $10 \mathrm{~cm}$ from the rim using Eqs. (10) and (11); (Fig. 1):

$$
\begin{aligned}
& l_{\mathrm{d}}=10+\frac{\left(h_{5}-h_{\mathrm{m}}\right)}{0.15} \\
& V=\frac{l_{\mathrm{d}}^{2} \times 0.15 \times 60}{2 \times 1000}
\end{aligned}
$$

\section{Results and discussion}

\section{1. changes in $\gamma_{\mathrm{fe}}$ during rainfall}

Both the total bulk densities $\left(\gamma_{t}\right)$ and the bulk densities of the fine earth fractions $\left(\gamma_{\mathrm{fe}}\right)$ for the different experiments are listed in Table 3. In standard soil physical procedures the total bulk density is usually measured (Childs and Flint, 1990). However, for a better understanding of the behaviour of a soil during heavy rainstorms, the distribution of pores in the fine earth is far more important. This parameter is reflected by the bulk density of the fine earth. A low $\gamma_{\mathrm{fe}}$ means a high porosity, which improves infiltration, can reduce capillary rise and hence the subsequent loss of water by evaporation and facilitates rooting (Childs and Flint, 1990; Poesen and Lavee, 1994). In practice, $\gamma_{\mathrm{re}}$ can be calculated from the $\gamma_{1}$ and the rock fragment content by volume $\left(R_{\mathrm{v}}\right)$ with Eq. (1). This was illustrated by Childs and Flint (1990), who produced diagrams of $\gamma_{\mathrm{fe}}$ against $R_{\mathrm{v}}$ for different $\gamma_{\mathrm{t}}$ values.

The relationships between $\gamma_{\mathrm{fe}}$ and the cumulative rainfall for the different treatments are plotted in Fig. 3. Rock fragment content by mass $\left(R_{\mathrm{m}}\right)$ is given in these graphs because rock fragment content by volume $\left(R_{\mathrm{v}}\right)$ increases during the experiments due to subsidence of the fine earth. In these graphs cumulative rainfall was used rather than its kinetic energy, because the cause of the changes in bulk density is considered to be a combination of destruction of aggregates by falling raindrops and changing soil strength with changing water content as soil water moves through the tilled layer (Onstad et al., 1984; Gusli et al., 1994). For moist soils, $\gamma_{\mathrm{fe}}$ increases rapidly during the initial phase, after which it seems to approach a constant value. For dry soils, swelling and subsidence seem to interact 
Table 3

Bulk density of the fine earth $\left(\gamma_{\mathrm{fe}}\right)$ and total bulk density $\left(\gamma_{\mathrm{t}}\right)$ during rainfall simulations where rock fragment content by mass $\left(R_{\mathrm{m}}\right)$, rock fragment size, rock fragment cover at the soil surface $\left(R_{\mathrm{c}}\right)$ and initial moisture content are variables

a. Bulk density $(\gamma)$ of control soils

\begin{tabular}{|c|c|c|c|c|c|c|c|}
\hline \multirow[t]{2}{*}{ Rock fragment size } & \multirow{2}{*}{$\begin{array}{l}R_{\mathrm{m}} \\
\left(\mathrm{kg} \mathrm{kg}^{-1}\right)\end{array}$} & \multirow{2}{*}{$\begin{array}{l}\text { Initial moisture } \\
\text { (g per } 100 \mathrm{~g} \text { ) }\end{array}$} & \multicolumn{5}{|c|}{$\gamma\left(\mathrm{kg} \mathrm{m}^{-3}\right)$ at cumulative rainfall $(\mathrm{mm})$} \\
\hline & & & 0 & 17.5 & 52.5 & 122.5 & 192.5 \\
\hline Control & 0 & 20.0 & 1135 & 1366 & 1389 & 1407 & 1405 \\
\hline Control & 0 & 19.4 & 1102 & 1238 & 1292 & 1366 & 1367 \\
\hline Control & 0 & 18.7 & 1126 & 1298 & 1349 & 1367 & 1375 \\
\hline Mean & 0 & 19.4 & 1121 & 1301 & 1344 & 1380 & 1382 \\
\hline Control & 0 & 3.4 & 1150 & 1156 & 1180 & 1216 & 1243 \\
\hline
\end{tabular}

b. Bulk density $(\gamma)$ of soils with surface rock fragment cover only

\begin{tabular}{|c|c|c|c|c|c|c|c|}
\hline \multirow{2}{*}{$\begin{array}{l}\text { Rock fragment size } \\
(\mathrm{cm})\end{array}$} & \multirow{2}{*}{$\begin{array}{l}R_{\mathrm{c}} \\
(\%)\end{array}$} & \multirow{2}{*}{$\begin{array}{l}\text { Initial moisture } \\
\text { (g per } 100 \mathrm{~g})\end{array}$} & \multicolumn{5}{|c|}{$\gamma\left(\mathrm{kg} \mathrm{m}^{-3}\right)$ at cumulative rainfall $(\mathrm{mm})$} \\
\hline & & & 0 & 17.5 & 52.5 & 122.5 & 192.5 \\
\hline $1.7-2.7$ & 30 & 20.6 & 1089 & 1237 & 1271 & 1325 & 1334 \\
\hline $1.7-2.7$ & 50 & 19 & 1105 & 1286 & 1306 & 1360 & 1379 \\
\hline \multicolumn{8}{|c|}{ c. Fine earth bulk density $\left(\gamma_{\mathrm{fe}}\right)$} \\
\hline \multirow{2}{*}{$\begin{array}{l}\text { Rock fragment size } \\
(\mathrm{cm})\end{array}$} & \multirow{2}{*}{$\begin{array}{l}R_{\mathrm{m}} \\
\left(\mathrm{kg} \mathrm{kg}^{-1}\right)\end{array}$} & \multirow{2}{*}{$\begin{array}{l}\text { Initial moisturc } \\
(\mathrm{g} \text { per } 100 \mathrm{~g})\end{array}$} & \multicolumn{5}{|c|}{$\gamma_{\mathrm{fe}}\left(\mathrm{kg} \mathrm{m}^{-3}\right)$ at cumulative rainfall $(\mathrm{mm})$} \\
\hline & & & 0 & 17.5 & 52.5 & 122.5 & 192.5 \\
\hline $1.7-2.7$ & 0.31 & 20 & 1105 & 1316 & 1364 & 1381 & 1392 \\
\hline $1.7-2.7$ & 0.52 & 20 & 989 & 1188 & 1246 & 1264 & 1266 \\
\hline $1.7-2.7$ & 0.52 & 19 & 945 & 1187 & 1221 & 1242 & 1247 \\
\hline $1.7-2.7$ & 0.77 & 21 & 652 & 790 & 794 & 799 & 803 \\
\hline 7.7 & 0.23 & 19.7 & 1107 & 1274 & 1339 & 1350 & 1357 \\
\hline 7.7 & 0.52 & 19.7 & 1081 & 1261 & 1300 & 1320 & 1328 \\
\hline 7.7 & 0.74 & 19.2 & 854 & 945 & 968 & 978 & 986 \\
\hline $1.7-2.7$ & 0.51 & 2.6 & 974 & 998 & 1098 & 1138 & 1149 \\
\hline $1.7-2.7$ & 0.77 & 2.6 & 651 & 698 & 725 & 735 & 735 \\
\hline \multicolumn{8}{|c|}{ d. Total bulk density $\left(\gamma_{t}\right)$} \\
\hline \multirow{2}{*}{$\begin{array}{l}\text { Rock fragment size } \\
(\mathrm{cm})\end{array}$} & \multirow{2}{*}{$\begin{array}{l}R_{\mathrm{m}} \\
\left(\mathrm{kg} \mathrm{kg}^{-1}\right)\end{array}$} & \multirow{2}{*}{$\begin{array}{l}\text { Initial moisture } \\
\text { (g per } 100 \mathrm{~g})\end{array}$} & \multicolumn{5}{|c|}{$\gamma_{\mathrm{t}}\left(\mathrm{kg} \mathrm{m}^{-3}\right)$ at cumulative rainfall $(\mathrm{mm})$} \\
\hline & & & 0 & 17.5 & 52.5 & 122.5 & 192.5 \\
\hline $1.7-2.7$ & 0.31 & 20 & 1329 & 1544 & 1595 & 1612 & 1622 \\
\hline $1.7-2.7$ & 0.52 & 20 & 1451 & 1646 & 1699 & 1714 & 1716 \\
\hline $1.7-2.7$ & 0.52 & 19 & 1404 & 1644 & 1675 & 1694 & 1698 \\
\hline $1.7-2.7$ & 0.77 & 21 & 1532 & 1691 & 1696 & 1701 & 1705 \\
\hline 7.7 & 0.23 & 19.7 & 1277 & 1446 & 1511 & 1522 & 1528 \\
\hline 7.7 & 0.52 & 19.7 & 1570 & 1743 & 1779 & 1797 & 1804 \\
\hline 7.7 & 0.74 & 19.2 & 1726 & 1818 & 1840 & 1850 & 1857 \\
\hline $1.7-2.7$ & 0.51 & 2.6 & 1429 & 1454 & 1554 & 1593 & 1603 \\
\hline $1.7-2.7$ & 0.77 & 2.6 & 1526 & 1584 & 1615 & 1626 & 1626 \\
\hline
\end{tabular}


during the initial phase (up to $17.5 \mathrm{~mm}$ rainfall), after which $\gamma_{\mathrm{fe}}$ increases (Fig. 3).

Onstad et al. (1984) proposed a model describing the evolution of bulk density due to water application to non-stoney soils. This model was applied to describe the relationship between bulk density of fine earth $\left(\gamma_{\mathrm{fe}} ; \mathrm{kg} \mathrm{m}^{-3}\right)$ and cumulative rainfall $\left(R_{\mathfrak{t}} ; \mathrm{cm}\right)$ using the initial fine earth bulk density $\left(\gamma_{\mathrm{ft}}\right)_{0}$ and a regression coefficient $\left(\beta_{\mathrm{b}} ; \mathrm{kg} \mathrm{m}^{-3}\right)$ in Eq. (12):

$$
\gamma_{\mathrm{fe}}=\left(\gamma_{\mathrm{fe}}\right)_{0}+\beta_{\mathrm{b}}\left[\frac{R_{\mathrm{t}}}{\left(1+R_{\mathrm{t}}\right)}\right]
$$

The results of the regression analyses for the different experiments show that
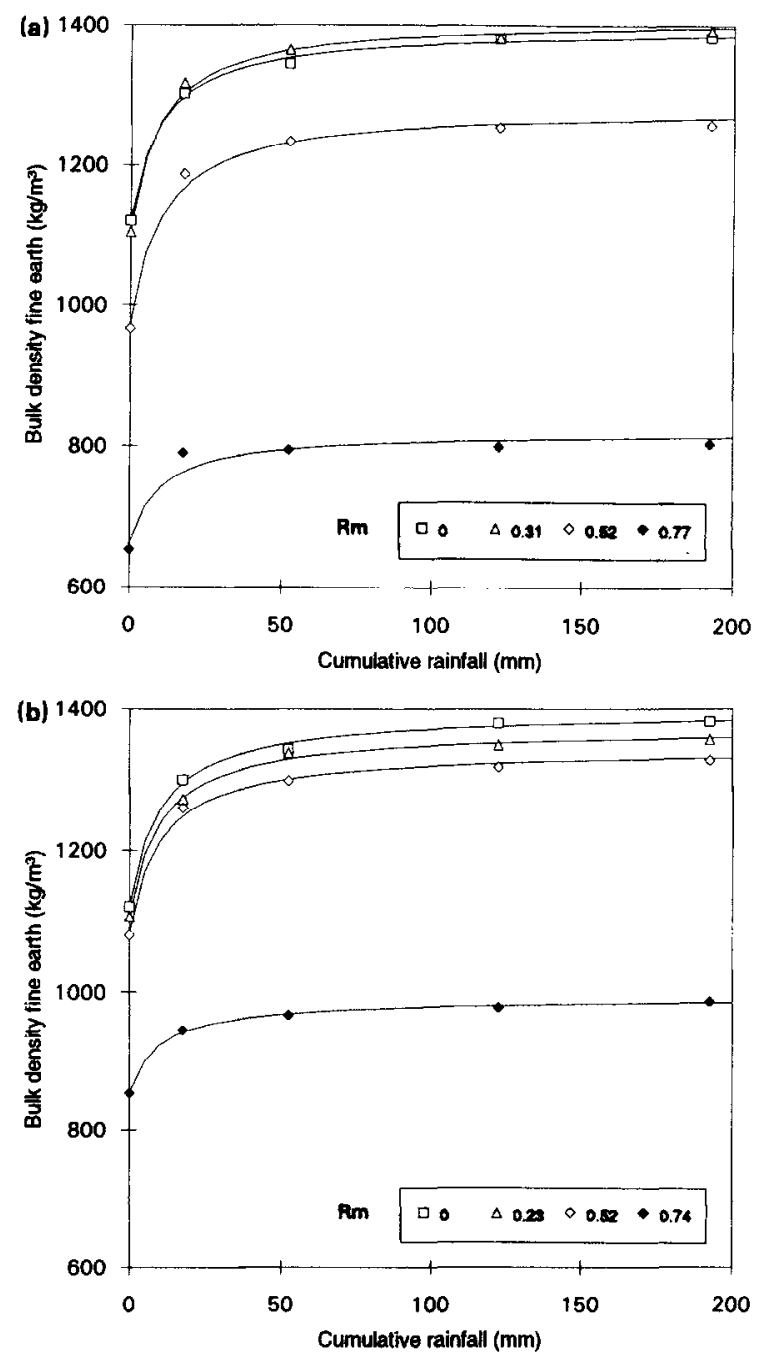

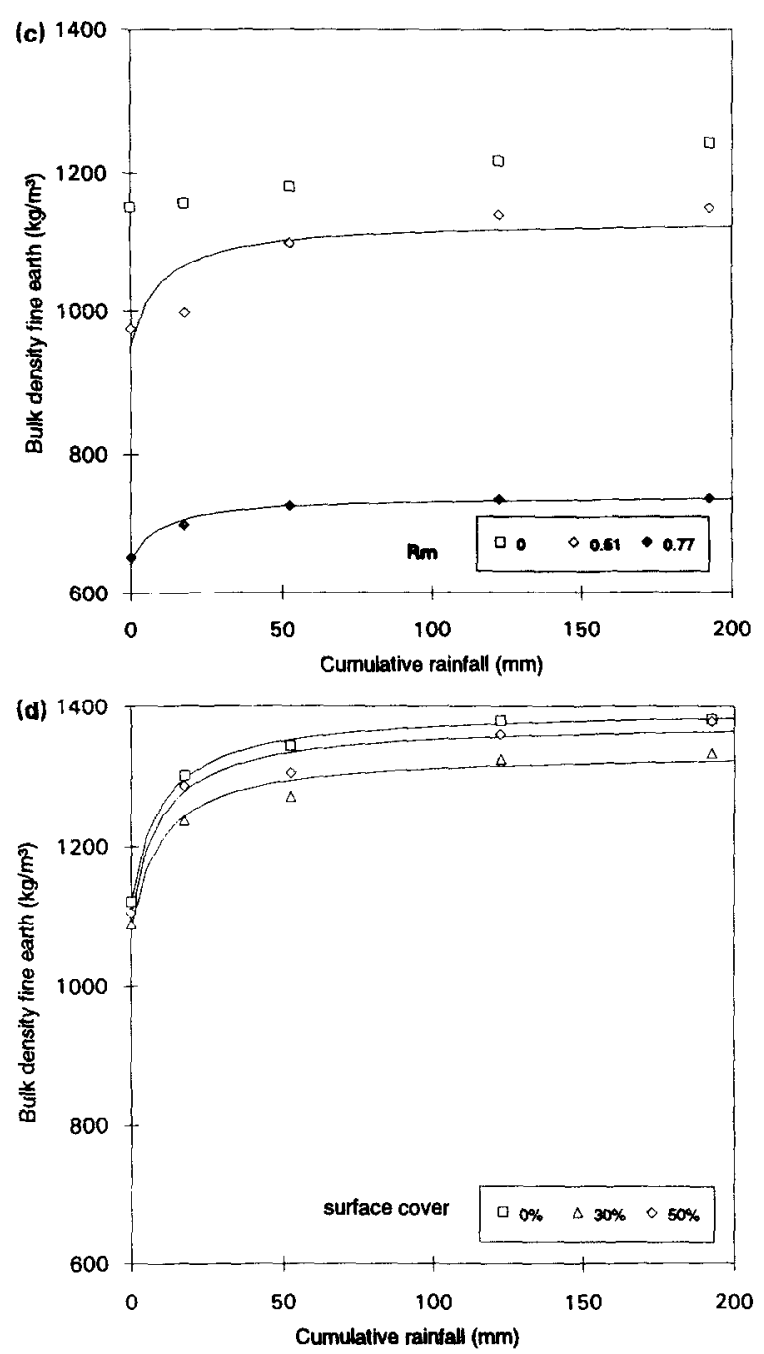

Fig. 3. Bulk density of the fine earth $\left(\gamma_{\mathrm{re}}\right)$ as function of the cumulative rainfall applied for different rock fragment contents by mass $\left(R_{\mathrm{m}} ; \mathrm{kg} \mathrm{kg}^{-1}\right)$. The regression lines were plotted using Eq. (12) and the parameters in Table 4. Four sets of experiments were performed using: (a) Small rock fragments $(1.7-2.7 \mathrm{~cm})$ in a moist soil $(20 \mathrm{~g}$ per $100 \mathrm{~g}) ;($ b) Large rock fragments $(7.7 \mathrm{~cm})$ in a moist soil $(20$ $\mathrm{g}$ per $100 \mathrm{~g})$; (c) Small rock fragments $(1.7-2.7 \mathrm{~cm})$ in a dry soil $(3 \mathrm{~g}$ per $100 \mathrm{~g})$; (d) Small rock fragments $(1.7-2.7 \mathrm{~cm})$ only at the surface of a moist soil $(20 \mathrm{~g}$ per $100 \mathrm{~g})$.

the model of Onstad et al. (1984) is very suitable for moist soils (Table 4 and Fig. 3). For dry soils, in particular with low rock fragment contents, the initial swelling is not accounted for. The rate of subsidence, expressed by the regression coefficient $\left(\beta_{\mathrm{b}}\right)$, was greatly reduced when $R_{\mathrm{m}}$ was more than $0.7 \mathrm{~kg} \mathrm{~kg}^{-1}$ (Table 4). According to Eq. (12), the maximum $\gamma_{\mathrm{fe}}$ can be estimated from the $\left(\gamma_{\mathrm{fe}}\right)_{0}$ and $\beta_{\mathrm{b}}$. A comparison of the $\gamma_{\mathrm{fe}}$ (Table 3 ) and $\left(\gamma_{\mathrm{fe}}\right)_{\mathrm{final}}$ (Table 4$)$ indicates that after $192.5 \mathrm{~mm}$ rainfall virtually no further change in bulk density (maximum $2 \%$ ) 
Table 4

Regression analyses of fine earth bulk density $\left(\gamma_{\mathrm{fe}}\right)$ against cumulative rainfall $\left(R_{\mathrm{t}} ; \mathrm{cm}\right)$ using the initial bulk density, $\left(\gamma_{\mathrm{fe}}\right)_{0}$ and a regression coefficient $\left(\beta_{\mathrm{b}}\right)$ for different rock fragment contents by mass $\left(R_{\mathrm{m}}\right)$ (Eq. 12; Onstad et al., 1984)

\begin{tabular}{|c|c|c|c|c|c|}
\hline Run $^{a}$ & $\begin{array}{l}R_{\mathrm{m}} \\
\left(\mathrm{kg} \mathrm{kg}^{-1}\right)\end{array}$ & $\begin{array}{l}\beta_{\mathrm{b}} \\
\left(\mathrm{kg} \mathrm{m}^{-3}\right)\end{array}$ & $\begin{array}{l}\left(\gamma_{\mathrm{fe}}\right)_{0} \\
\left(\mathrm{~kg} \mathrm{~m}^{-3}\right)\end{array}$ & $r^{2}$ & $\begin{array}{l}\left(\gamma_{\mathrm{ft}}\right)_{\mathrm{final}}^{\mathrm{b}} \\
\left(\mathrm{kg} \mathrm{m}^{-3}\right)\end{array}$ \\
\hline SM & 0 & 274.2 & 1122 & 0.99 & 1396 \\
\hline $\mathrm{SM}$ & 0.31 & 301 & 1110 & 0.99 & 1411 \\
\hline SM & 0.52 & 307.7 & 973 & 0.99 & 1281 \\
\hline SM & 0.77 & 159.3 & 661 & 0.94 & 820 \\
\hline LM & 0.23 & 265.3 & 1107 & 0.99 & 1373 \\
\hline LM & 0.52 & 258.6 & 1085 & 0.99 & 1343 \\
\hline LM & 0.74 & 136.2 & 855 & 0.99 & 991 \\
\hline $\mathrm{SD}$ & 0 & 76.2 & 1138 & $0.57^{\mathrm{c}}$ & 1214 \\
\hline $\mathrm{SD}$ & 0.51 & 178.1 & 952 & $0.76^{\mathrm{d}}$ & 1130 \\
\hline \multirow[t]{2}{*}{ SD } & 0.77 & 89.4 & 649 & 0.98 & 738 \\
\hline & Surface cov & & & & \\
\hline SU & 30 & 248.6 & 1085 & 0.98 & 1333 \\
\hline SU & 50 & 272.5 & 1105 & 0.98 & 1377 \\
\hline
\end{tabular}

aSM, small rock fragments in moist soil; LM, large rock fragments in moist soil; SD, small rock fragments in dry soil; $\mathrm{SU}$, surface rock fragment cover.

bFinal fine earth bulk density.

'Not significant.

dignificant at $P<0.1$

will occur. The behaviour of dry soils containing rock fragments deserves some more attention (Fig. 3c). In the initial phase (up to about $17.5 \mathrm{~mm}$ rainfall) swelling is an important feature which is most prominent in dry soils without rock fragments because of the large proportion of fine earth. After this stage, the trend for dry soils is comparable with that of moist soils, although swelling in the initial stage makes it difficult to calculate reliable regressions (Table 4 and Fig. 3c).

During the experiments the surface is washed by the simulated rainfall, increasing the rock fragment cover (Fig. 4). In the initial phase, soil is washed mainly vertically into the top layer, while during the final stage of the experiment some erosion as well as deposition within the plot box occur (Tables 1 and 5). It should be noted that sediment loss by erosion and deposition of sediment within the plot box were responsible for only at the most $3 \%$ of the weight loss and $1.5 \%$ of the change in volume.

\subsection{Effects of rock fragment content and size}

The effects of rock fragment content and size on subsidence rates can be estimated from the relation between the regression coefficient $\left(\beta_{\mathrm{b}} ; \mathrm{Eq} .12\right)$ in the model of Onstad et al. (1984) and the rock fragment content by mass $\left(R_{\mathrm{m}}\right)$. For both soils with small and large rock fragments, the subsidence rate increases up 

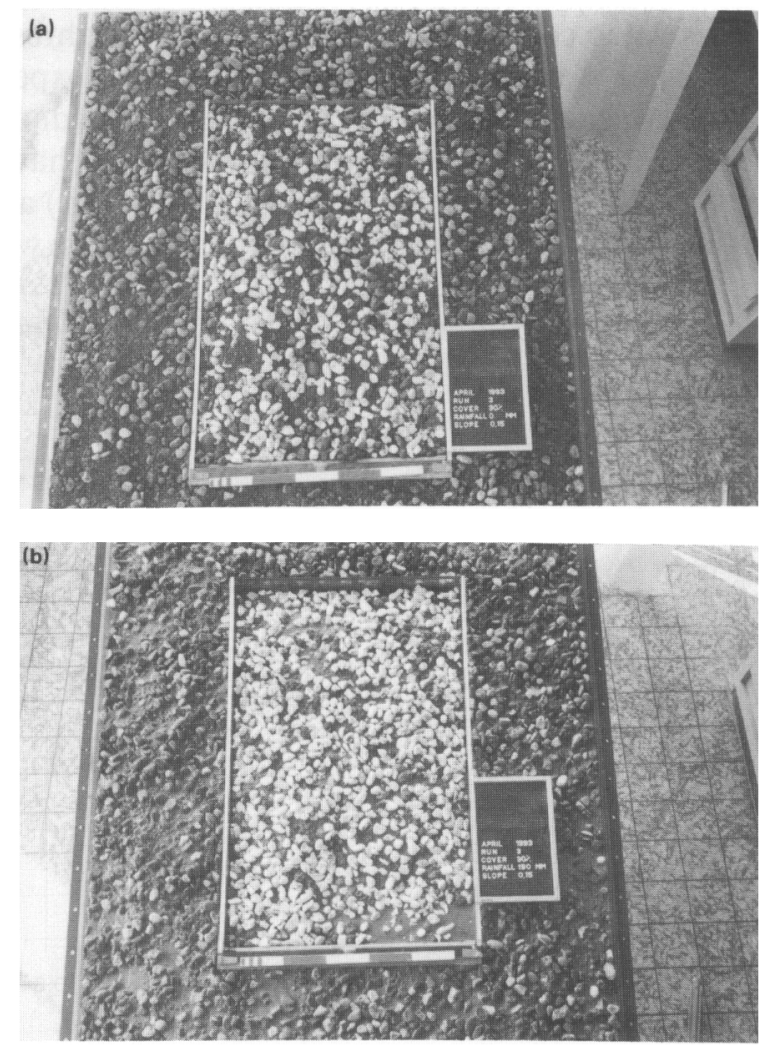

Fig. 4. Surface of a moist soil with $0.52 \mathrm{~kg} \mathrm{~kg}^{-1}$ rock fragments: (a) before the experiment; rock fragment cover $35 \%$; and (b) after $190 \mathrm{~mm}$ of cumulative rainfall; rock fragment cover, $44 \%$. Length of scale equals $50 \mathrm{~cm}$.

Table 5

Total soil loss by runoff and percolation as well as moisture content after the experiments

\begin{tabular}{lllcccc}
\hline Rock fragment size & $\begin{array}{l}R_{\mathrm{m}} \\
\left(\mathrm{kg} \mathrm{kg}^{-1}\right)\end{array}$ & $\begin{array}{l}\text { Rainfall } \\
(\mathrm{mm})\end{array}$ & $\begin{array}{l}\text { Runoff } \\
(\mathrm{mm})\end{array}$ & $\begin{array}{l}\text { Percolation } \\
(\mathrm{mm})\end{array}$ & $\begin{array}{l}\text { Sediment } \\
(\mathrm{g})\end{array}$ & $\begin{array}{l}\text { Moisture } \\
(\mathrm{g} \text { per 100 } \mathrm{g})\end{array}$ \\
\hline Control & 0 & 205.3 & 139.8 & 6.8 & 555 & 24.7 \\
$1.7-2.7$ & 0.52 & 190.3 & 0 & 136.4 & 399 & 27.4 \\
7.7 & 0.74 & 197.3 & 0 & 155.0 & 354 & 27.2 \\
Control & 0 & 205.8 & 115.5 & 0 & 2726 & 28.8 \\
$1.7-2.7$ & 0.51 & 193.8 & 105.5 & 0 & 1098 & 30.1 \\
$1.7-2.7$ & 0.77 & 195.3 & 0 & 111.3 & 95 & 34.6 \\
\hline
\end{tabular}

to $R_{\mathrm{m}}$ values of $0.52 \mathrm{~kg} \mathrm{~kg}^{-1}$. For higher $R_{\mathrm{m}}$ values subsidence rates decrease (Table 4). According to Ravina and Magier (1984) the decrease in subsidence rates at high rock fragment contents can be explained by the formation of a skeleton of rock fragments which sustains the soil structure. Childs and Flint (1990) draw the limit between non-skeletal and skeletal soils at a rock fragment content 
of $0.35 \mathrm{~m}^{3} \mathrm{~m}^{-3}$. This value corresponds very well with the threshold rock fragment content of $0.50 \mathrm{~kg} \mathrm{~kg}^{-1}$ at which a skeleton forms in our experiments (Table 1 ). The increased effectiveness of small rock fragments in reducing soil subsidence reported by Saini and Grant (1980), who studied the behaviour of agricultural soils with small $(0.64-1.27 \mathrm{~cm})$, medium $(1.27-2.54 \mathrm{~cm})$ and large $(2.54-$ $3.81 \mathrm{~cm}$ ) rock fragments during application of dynamic loads, was not found in our experiments.

The effects of rock fragment content and size on final bulk density can be ob-
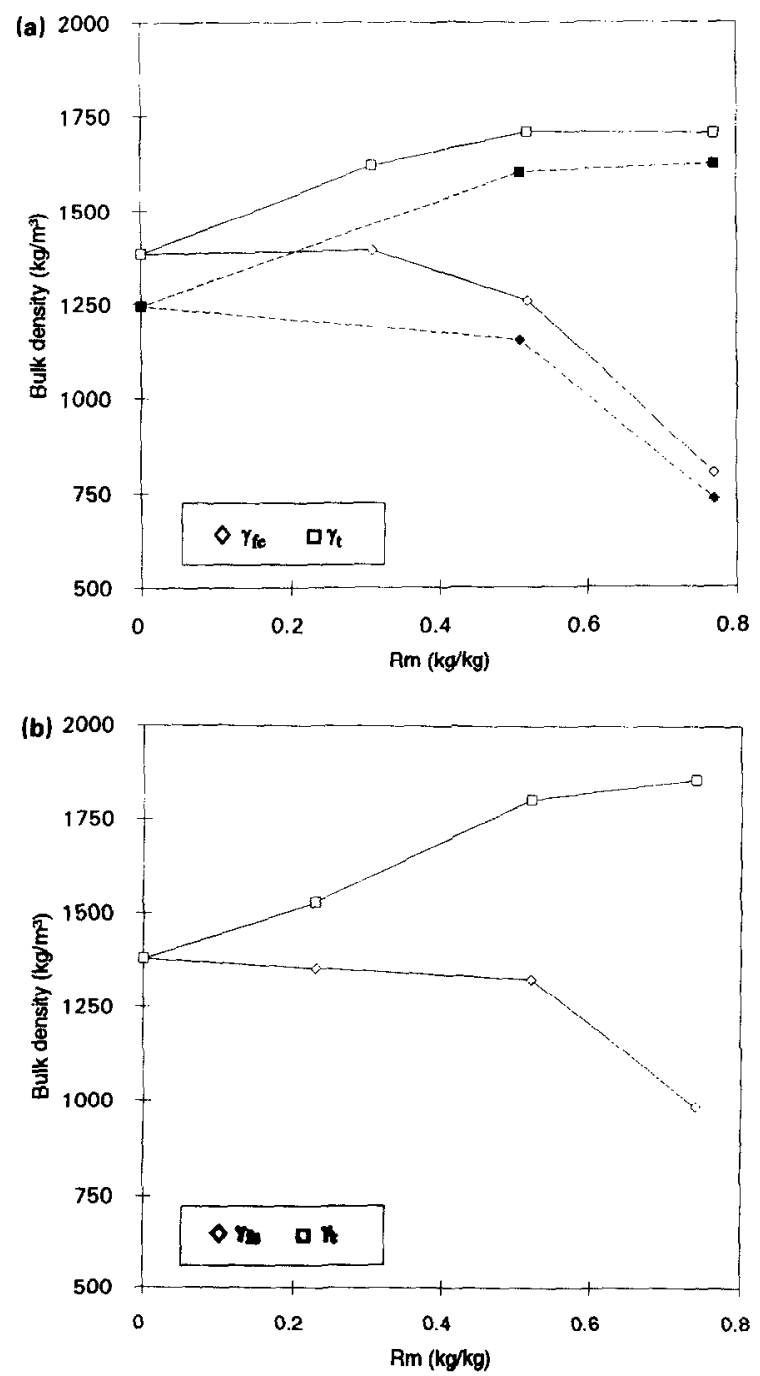

Fig. 5. Relationship between bulk density $\left(\gamma_{\mathrm{fe}}\right.$ and $\left.\gamma_{\mathrm{t}}\right)$ and rock fragment content by mass $\left(R_{\mathrm{m}}\right)$ after the application of $192.5 \mathrm{~mm}$ of rainfall for: (a) Small rock fragments $(1.7-2.7 \mathrm{~cm}$ ) in a moist soil $(20 \mathrm{~g}$ per $100 \mathrm{~g}$, open symbols) and in a dry soil $(3 \mathrm{~g}$ per $100 \mathrm{~g}$, closed symbols); (b) Large rock fragments $(7.7 \mathrm{~cm})$ in a moist soil $(20 \mathrm{~g}$ per $100 \mathrm{~g})$. 


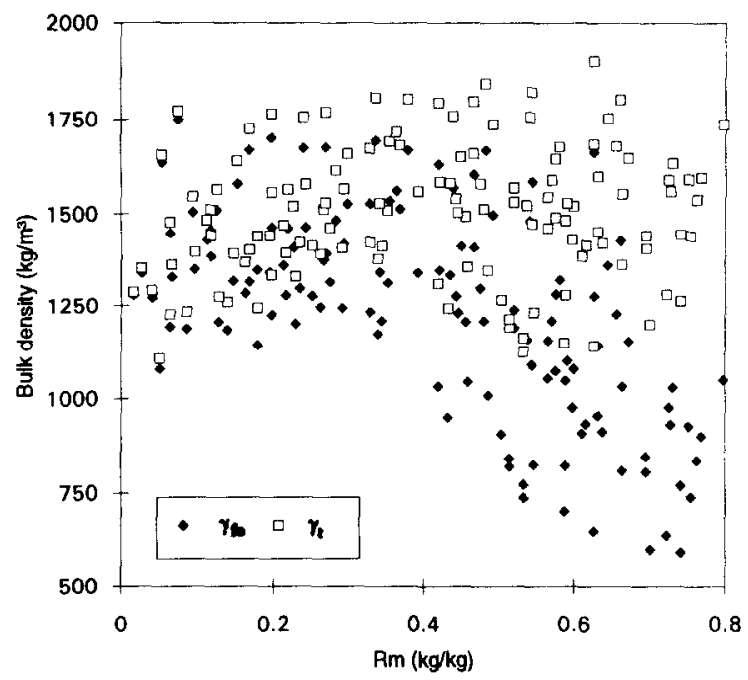

Fig. 6. Relationship between rock fragment content by mass $\left(R_{\mathrm{m}}\right)$ and bulk density $\left(\gamma_{\mathrm{fe}}\right.$ and $\left.\gamma_{\mathrm{t}}\right)$ for a brown cultivated soil with limestone fragments developed on a river terrace (Ebro basin, Spain). Data extracted from Alberto 1971. Figure reproduced with permission from Poesen and Lavee, 1994, Catena, $23: 7$.

served by plotting bulk densities after $192.5 \mathrm{~mm}$ of cumulative rainfall against rock fragment content (Fig. 5). As expected, total bulk density $\left(\gamma_{t}\right)$ increases with increasing rock fragment content (Fig. 5). However, $\gamma_{\mathrm{fe}}$ is negatively influenced by rock fragment content beyond a critical value for $R_{\mathrm{m}}: 0.30$ for small and $0.50 \mathrm{~kg} \mathrm{~kg}^{-1}$ for large rock fragments (Fig. 5). Furthermore, at comparable $R_{\mathrm{m}}$ values, $\gamma_{\mathrm{fe}}$ and $\gamma_{\mathrm{t}}$ are generally lower for soils containing small rock fragments.

The decrease of $\gamma_{\mathrm{fe}}$ with rock fragment content found during the final stage of our experiments is corroborated by the results from field studies both in cultivated fields (Fig. 6: Alberto, 1971 after Poesen and Lavee, 1994) and in noncultivated, forest soils (Fig. 7; Van Wesemael and Veer, 1992). The scatter in the graphs from field measurements is very large (Figs. 6 and 7). This is inevitable since the results are obtained from rather large areas, where soil conditions are variable.

\subsection{Effects of initial moisture content of the fine earth}

The aggregate stability of dry soils is in general lower than that of moist soils (e.g. Cernuda et al., 1954; Haynes and Swift, 1990; Le Bissonais and Singer, 1992). The low aggregate stability might also influence subsidence of the plough layer, when rain falls on a dry, tilled soil, as is often the case in Mediterranean environments. From the experiments it can be concluded that low initial moisture content (2.6-3.4 g per $100 \mathrm{~g}$ ) of the fine earth limits subsidence (Fig. 3c). This is attributed to swelling of the fine earth during the first $17.5 \mathrm{~mm}$ of rainfall (Table 3). Apart from the lower $\gamma_{\mathrm{fe}}$ and $\gamma_{\mathrm{t}}$ in dry soils, attributed to swelling of 

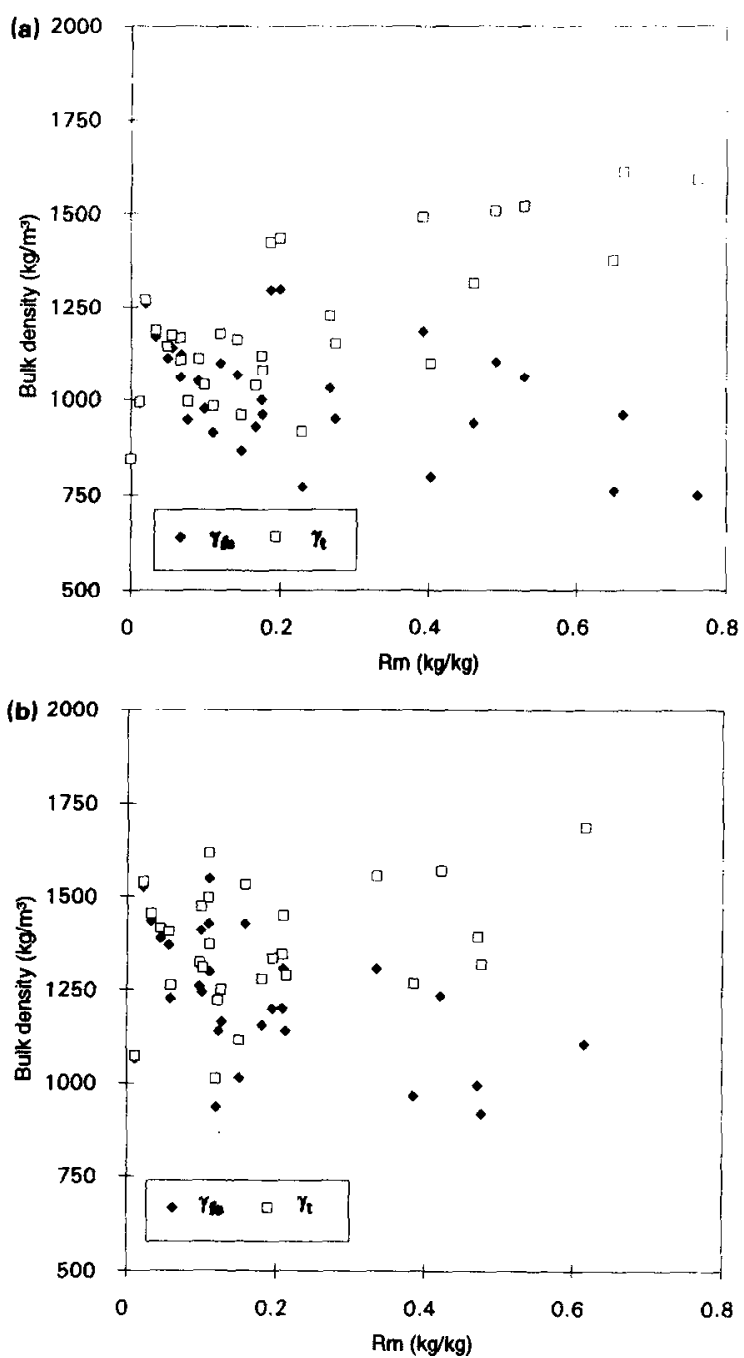

Fig. 7. Relationship between rock fragment content by mass $\left(R_{\mathrm{m}}\right)$, fine earth bulk density $\left(\gamma_{\mathrm{fe}}\right)$ and total bulk density $\left(\gamma_{t}\right)$ in forest soils on phyllite (Tuscany, Italy). Data extracted from Van Wesemael and Veer (1992). Samples were taken at two depths: (a) $0-5 \mathrm{~cm}$ and (b) $10-15 \mathrm{~cm}$.

the fine earth, the effects of rock fragment content are comparable with those in moist soils (Fig. 5a).

\subsection{Effects of a surface rock fragment cover}

Rock fragments at the soil surface, which dissipate the kinetic energy from falling raindrops, do not seem to have a significant influence on subsidence of the plough layer (Table 4). Therefore, it can be stated that the changing soil strength 
with changing water content, mentioned by Onstad et al. (1984) and Gusli et al. (1994), is the most important process in physical degradation of the plough layer.

It has to be noted that in this paper physical degradation of the entire plough layer is treated. A rock fragment surface cover does influence the degree of subsidence in the uppermost millimetres resulting in surface sealing and the formation of a thin, dense crust (Poesen and Ingelmo-Sanchez, 1992).

\subsection{Physical characteristics of soils containing rock fragments}

Fig. 8 depicts the distribution of the volumes occupied by rock fragments, fine earth and pores after the fine earth/rock fragment mixtures had received 192.5 $\mathrm{mm}$ of rainfall. Although the distinction between small pores and macropores is not based on soil moisture retention characteristics, it gives a practical indication of the capacity for rapid drainage after rainstorms. At low and medium rock fragment contents $\left(R_{\mathrm{m}}<0.50 \mathrm{~kg} \mathrm{~kg}^{-1}\right)$, the total pore volume decreases and the ratio between the volume of pores and volume of fine earth increases with $R_{\mathrm{m}}$ (Fig. 8 ). At high rock fragment contents $\left(R_{\mathrm{m}}>0.50 \mathrm{~kg} \mathrm{~kg}^{-1}\right)$, there is a strong increase in macropores with increasing $R_{\mathrm{m}}$ (Fig. 8). Both effects at low and high $R_{\mathrm{m}}$ cause deeper penetration of the wetting front into the soil with rock fragments compared to rock-fragment-free soils; reducing evaporation losses and enhancing ground water recharge. These effects are particularly important in dry climates, where wheat biomass production, for example, is directly related to amount of rainfall (Kosmas et al., 1993).

An additional effect of rock fragments is the concentration of inputs in the fine earth fraction (e.g. rainfall, organic matter and fertilizers; Childs and Flint, 1990; Poesen and Lavee, 1994). The more intense flow of water through the fine earth fraction in the soils with large amounts of rock fragments apparently does not have a negative effect on the stability of the soil structure. The effect of organic matter concentration on $\gamma_{\text {fe }}$, however, can clearly be seen in forest soils with slowly decomposing litter, as in the pine forest stand in southern Tuscany (Fig. 9; Van Wesemael and Veer, 1992). Although there is a considerable variation, the carbon concentration of the fine earth increases with increasing rock fragment content (Fig. 9). The data of Flint and Childs (1984) from 40 topsoils in southwest Oregon do not show a relationship between organic matter content and $R_{\mathrm{v}}$. This can be explained by the differences in conditions which determine the accumulation of soil organic matter between the sites. The data from the site of Van Wesemael and Veer (1992) used in Fig. 9 can be considered to be quite homogeneous in this respect.

\subsection{Management of soils containing rock fragments}

The removal of rock fragments from agricultural soils, if economically feasible, is practised in order to facilitate tillage and to reduce damage of root crops (e.g. potatoes and sugar beets; Saini and Grant, 1980; Witney, 1984). From our experiments it can be concluded that large amounts of rock fragments have a posi- 
tive effect on soil structure. In particular small rock fragments $(1.7-2.7 \mathrm{~cm})$ are responsible for maintaining low $\gamma_{\mathrm{fe}}$ and high macroporosity in topsoils (Figs. 5 and 8). Therefore, size reduction of rock fragments rather than removal seems to be a promising management technique. Chow et al. (1992), however, demonstrated that in practice there are some disadvantages in mechanical rock crushing. They concluded that care should be taken to avoid too severe crushing of
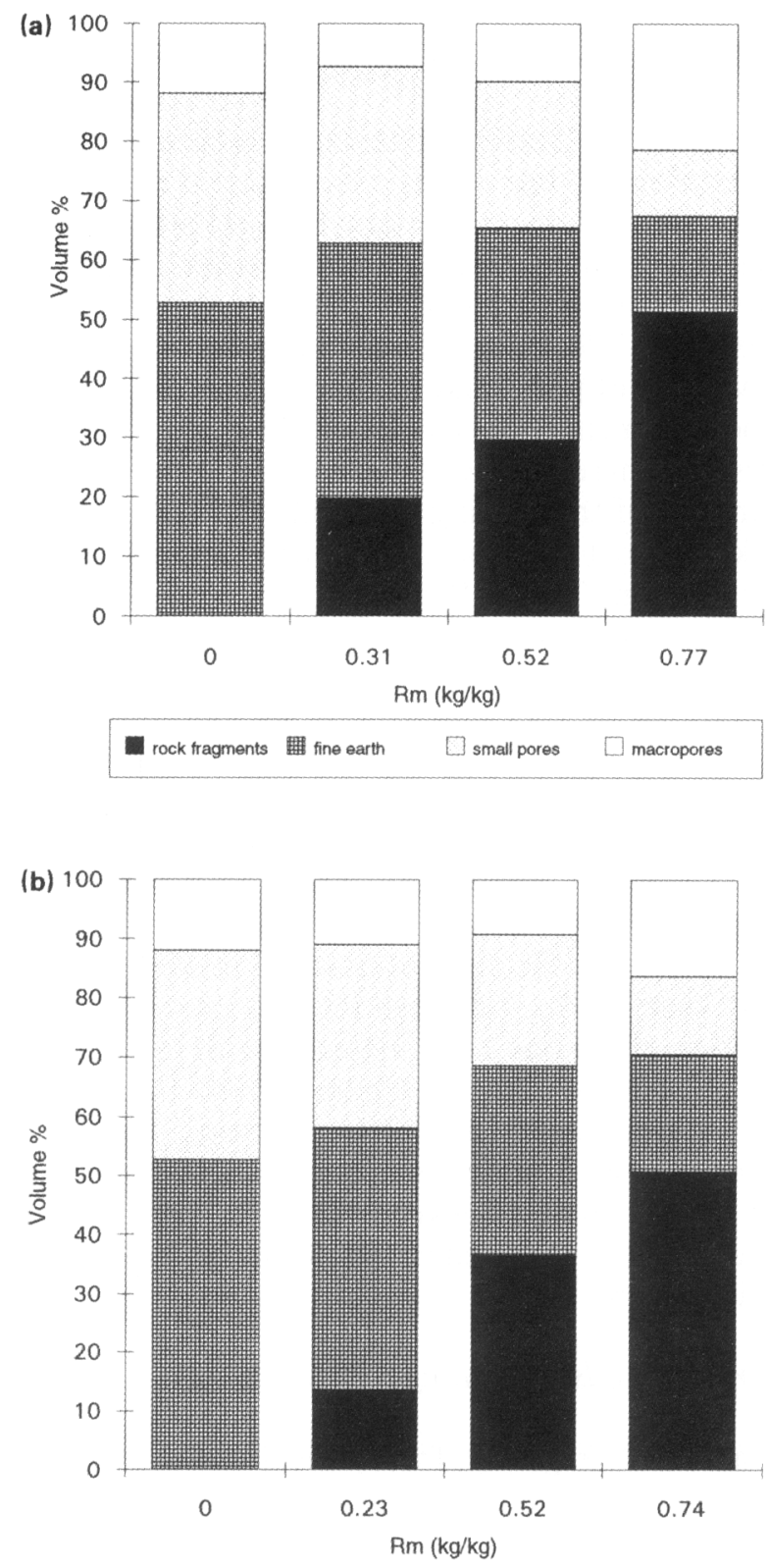

rock fragments fine earth $\square$ small pores $\square$ macropores 


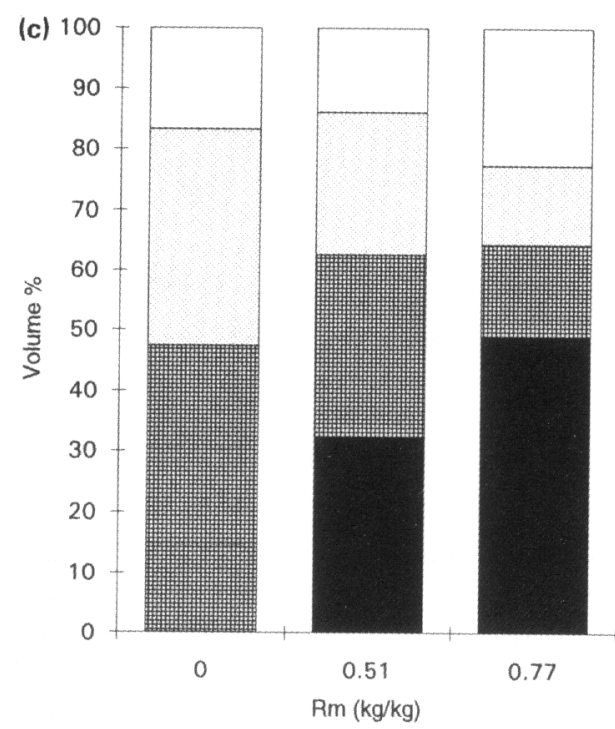

$$
\text { rock fragments } \quad \square \text { small pores } \quad \square \text { macropores }
$$

Fig. 8. Volumes occupied by rock fragments, fine earth, small pores and macropores as a function of rock fragment content by mass $\left(R_{\mathrm{m}}\right)$ after $192.5 \mathrm{~mm}$ of rainfall: (a) Small rock fragments (1.7-2.7 $\mathrm{cm})$ in a moist soil $(20 \mathrm{~g}$ per $100 \mathrm{~g}) ;(\mathrm{b})$ Large rock fragments $(7.7 \mathrm{~cm})$ in a moist soil $(20 \mathrm{~g}$ per 100 $\mathrm{g})$; (c) Small rock fragments $(1.7-2.7 \mathrm{~cm})$ in a dry soil $(3 \mathrm{~g}$ per $100 \mathrm{~g})$.

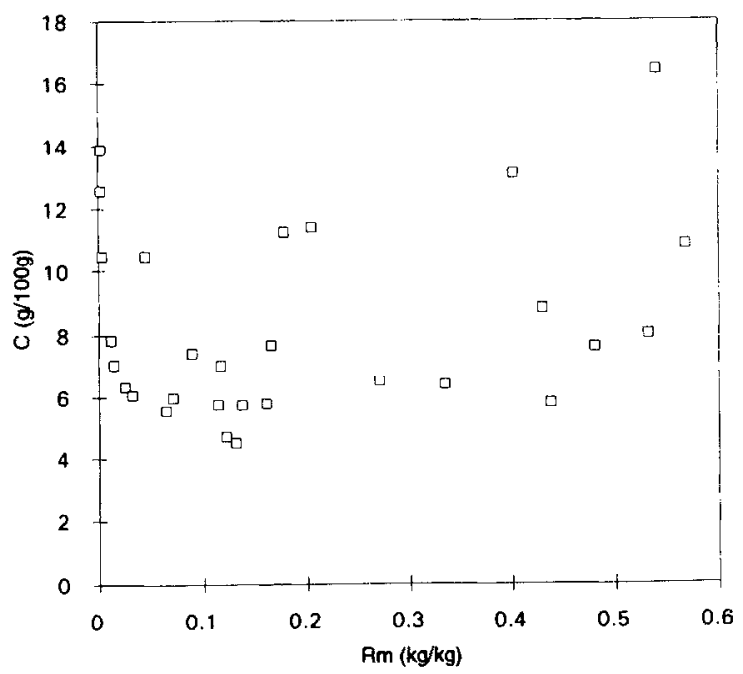

Fig. 9. Relationship between carbon content $(C)$ in the fine earth and rock fragment content by mass $\left(R_{\mathrm{m}}\right)$ for the topsoil $(0-5 \mathrm{~cm})$ of a Mediterranean pine forest. Data extracted from Van Wesemael and Veer (1992). 
rock fragments (2-3 $\mathrm{mm})$ and to separate large soil aggregates from rock fragments before crushing.

\section{Conclusions}

Soil subsidence, expressed by the increase of bulk density of tilled soils, due to rainfall is rapid during the initial stage (up to $17.5 \mathrm{~mm}$ of cumulative rainfall) and after that becomes negligible (up to $192.5 \mathrm{~mm}$ cumulative rainfall). For soils containing rock fragments, the relation between bulk density of the fine earth and cumulative rainfall can be well represented by Eq. (12).

The distinction between skeletal soils (rock fragment content of more than 0.35 $\mathrm{m}^{3} \mathrm{~m}^{-3}$ ) and non-skeletal soils appears to be useful, since the influence of rock fragments on subsidence is visible only beyond a threshold rock fragment content. Rock fragments at the soil surface do not influence subsidence of the entire plough layer, which points to the dominance of water passing through the soil over transfer of kinetic energy by falling raindrops as the main mechanism of subsidence of the plough layer. The effect of rock fragments on final bulk density of the fine earth is strongest when rock fragments are small $(1.7-2.7 \mathrm{~cm})$ and dispersed throughout the soil profile.

The high macroporosity of soils containing more than $0.50 \mathrm{~kg} \mathrm{~kg}^{-1}$ rock fragments will enhance deeper penetration of rainfall into the soil compared with soils without rock fragments. In addition, the concentration of organic matter in the fine earth fraction has a beneficial effect on soil structure. Therefore, the removal of rock fragments from agricultural fields should be discouraged. If economically feasible, mechanical reduction of their size to $1.7-2.7 \mathrm{~cm}$ seems to be a good alternative.

\section{Acknowledgements}

The research for this paper was carried out as part of the MEDALUS II (Mediterranean Desertification and Land Use) collaborative research project. MEDALUS II was funded by the European Union under its Environmental Programme, contract number EV5V 0128 , and the support is gratefully acknowledged. The last author's participation in the experiments was supported financially by the Portugal-Belgium Scientific and Cultural Agreement. He wishes to thank the Instituto Nacional de Investigacao Cientifica (Portugal), the Ministry of the Flemish Community (Belgium) and the Escola Superior Agrária, Instituto Politecnico de Bragança (Portugal). The authors also wish to thank Dr. G. Govers for providing information on the laser microrelief meter. 


\section{References}

Alberto, F., 1971. Considérations sur la pierrosité des sols bruns à croûte calcaire du bassin de l'Ebre. Bull. Rech. Agron. Gembloux, 6: 180-185.

Allmaras, R.R., Burwell, R.E. and Holt, R.F., 1967. Plow layer porosity and surface roughness from tillage as affected by initial porosity and soil moisture at tillage time. Soil Sci. Soc. Am. Proc. 30: $550-556$.

Cernuda, C.F., Smith, R.M. and Vicente-Chandler, J., 1954. Influence of initial soil moisture condition on resistance of macro-aggregates to slaking and water drop impact. Soil Sci., 77: 19-27.

Childs, S.W. and Flint, A.L., 1990. Physical properties of forest soils containing rock fragments. In: S.P. Gessel, D.S. Lacate, G.F. Weetman and R.F. Powers (Editors), Sustained Productivity of Forest Soils. Proceedings of the 7th North American Forest Soils Conference. University of British Columbia, Faculty of Forestry Publication, Vancouver, B.C., pp. 95-121.

Chow, T.L., Rees, H.W. and Moodie, R.L., 1992. Effects of stone removal and stone crushing on soil properties, erosion and potato quality. Soil Sci., 153: 242-249.

FAO, 1979. A Provisional Methodology for Soil Degradation Assessment. FAO. Rome, 84 pp.

Flint, A.L. and Childs, S.W., 1984. Physical properties of rock fragments and their effect on available water in skeletal soils. In: J.D. Nichols, P.L. Brown and W.J. Grant (Editors), Erosion and Productivity of Soils Containing Rock Fragments. Soil Sci. Soc. Am., Spec. Publ. 13, Madison. WI, pp. 99-103.

Gusli, S., Cass, A., Macleod, D.A. and Blackwell, P.S., 1994. Structural collapse and strength of some Australian soils in relation to hardsetting: I. Structural collapse on wetting and draining. Eur. J. Soil Sci., 15: 15-21.

Haynes, R.J. and Swift, R.S., 1990. Stability of soil aggregates in relation to organic constituents and soil water content. J. Soil Sci., 41: 73-83.

Kosmas, C.S., Danalatos, N.G., Moustakos, N., Tsatiris, B., Kallianou, Ch., and Yassoglou, N., 1993. The impacts of parent material and landscape position on drought and biomass production of wheat under semi-arid conditions. Soil Technol., 6: 337-349.

Le Bissonais. Y. and Singer, M.J., 1992. Crusting, runoff and erosion response to soil water content and successive rainfalls. Soil Sci. Soc. Am. J., 56: 1898-1903.

Magier, J. and Ravina, I., 1984. Rock fragments and soil depth as factors in land evaluation of terra rossa. In: J.D. Nichols, P.L. Brown and W.J. Grant (Editors), Erosion and Productivity of Soils Containing Rock Fragments. Soil Sci. Soc. Am., Spec. Publ.13, Madison, WI, pp. 99-103.

Mehuys, G.R., Stolzy, L.H., Letey, J. and Weeks, L.V., 1975. Effects of stones on the hydraulic conductivity of relatively dry desert soils. Soil Sci. Soc. Am. Proc., 39: 37-42.

Miller, F. and Guthrie, R., 1984. Classification and distribution of soils containing rock fragments in the United States. In: J.D. Nichols, P.L. Brown and W.J. Grant (Editors), Erosion and Productivity of Soils Containing Rock Fragments. Soil Sci. Soc. Am., Spec. Publ. 13, Madison. WI. pp. 112.

Onstad, C.A., Wolfe, M.L., Larson, C.L. and Slack, D.C., 1984. Tilled soil subsidence during repeated wetting. Trans. ASAE, 27: 733-736.

Poesen, J. and Bunte, K., 1995. Effects of rock fragments on desertification processes in Mediterranean environments. In: J. Thornes and J. Brandt (Editors), Mediterranean Desertification and Land Use. J. Wiley and Sons, Chichester (in press).

Poesen, J. and Ingelmo-Sanchez, F., 1992. Runuff and sediment yield from topsoils with different porosity as affected by rock fragment cover and position. Catena, 19:451-474.

Poesen, J. and Lavee, H., 1994. Rock fragments in topsoils: Significance and processes. Catena, 23: $1-28$.

Poesen, J., Ingelmo-Sanchez, F. and Mücher, H., 1990. The hydrological response of soil surfaces to rainfall as affected by cover and position of rock fragments in the top layer. Earth Surf. Process. Landforms, 15: 653-671.

Ravina, I. and Magier, J., 1984. Hydraulic conductivity and water retention of clay soils containing coarse fragments. Soil Sci. Soc. Am. J., 48: 736-740. 
Römkens, M.J.M., Wang, J.Y. and Darden, R.W., 1988. A laser microrelief meter. Trans. ASAE, 31 : 408-413.

Saini, G.R. and Grant, W.J., 1980. Long-term effects of intensive cultivation on soil quality in the potato-growing areas of New Brunswick (Canada) and Maine (USA). Can. J. Soil Sci., 60: 421428.

Van Wesemael, B. and Veer, M.A.C., 1992. Soil organic matter accumulation, litter decomposition and humus forms under Mediterranean-type forests in southern Tuscany (Italy ). J. Soil Sci., 43: 133-144.

Witney, B.D., 1984. The investigation and promotion of stone/clod windrowing for potato production systems. R. D. Agric., 1: 1-20. 